\title{
A Review of Mindfulness and Social Media Excessive Use
}

\author{
Xiru Sun*
}

\author{
${ }^{1}$ University of California, Los Angeles, United States \\ ${ }^{*}$ Corresponding author email: sxrharbin@g.ucla.edu
}

\begin{abstract}
The social networking has become an inseparable part of human being's daily life across different age groups. More people are growing an obsession to the online platform that this problematic behaviour has caused negative impact toward people's life. Solutions for this excessive behaviour have been intensively discussed but still remained unsolved. Mindfulness, discussed in multiple articles, has a direct or indirect impact on the excessive usage of the social media. Therefore, this paper would review literatures about the relationship between mindfulness and social media excessive use. These major topics will be discussed as following: if mindfulness could really help to reduce the social media addictive behaviour; the way that individuals with higher trait mindfulness different from those with lower trait mindfulness in regards to the problematic social media use, and the role mindfulness play in the intervention for the excessive use of social media addiction. These results shed light on if and how mindfulness training sessions should be adopted by the school, community, and working environment.
\end{abstract}

Keywords: Social media addiction, Social networking websites, Social media addiction, Mindfulness, Mindfulness-based stressful reduction, Mindfulness-based cognitive therapy

\section{INTRODUCTION}

Tik Tok, Facebook, Twitter, Instagram, Snapchat, and computer mediated communications (CMC) have been more common than ever as tools to connect remotely with peers, families, and friends [1]. Convenient as they are, social media would easily engage individuals into unhealthy and uncontrollable behaviors resulting in excessive use of social media [2]. There is a growing number of literatures that recognize the importance of the impact of excessive use of social media on adolescents' emotion, cognition, academic performance, and interpersonal relationships, etc. [3]. Not surprisingly, as early as 1983, scholars have already proposed to categorize excessive use of social media as a behavioral addiction involves diverse compulsive behaviors [4]. Not until DSM-5 when gaming addiction was being categorized as 'Internet gaming disorder' and the excessive use of social media was included in the Appendix to hold for further consideration [5] did excessive use of social media eventually become officially recognized. The inclusion brought more interests to the researchers to focus on clinical, diagnostic, and psychopathological features of behavioral addiction, including excessive use of social media [6].

Although the results of mindfulness techniques have been a controversial and disputed topic within the field of addiction, this intervention has still originally been applied for substance use disorder [7, 8]. Thus, it has been extended to be used for mitigating the excessive use of social media $[9,10]$. As it is controversial, few papers have been able to draw on any systematic research into the discussion on the application of mindfulness and the excessive use of social media. This paper will thus focus on these aspects reviewing 11 articles to identify 1 ). if mindfulness could help reduce the social media addictive behavior, and 2). the role of mindfulness plays in the intervention for the excessive use of social media addiction.

\subsection{Why Studying Social Media Excessive Use}

The convenient availability of Internet has brought about the concern of Internet-related obsessive behaviors [11]. The existing researches have examined the negative consequences of excessive use of social media, including but not limited to physical discomfort (lack of sleep, dizziness), emotional problem 
(depression, anxiety, imagined phone signals), interpersonal conflicts (family, friend, partner), and lowered work efficiency and academic performance [3]. In a survey testing 1893 participants, the more time students spend on Facebook, the lower their total GPA become [12].

Important as the problem is, if overly use of social media should be considered as a form of addiction has been discussed for decades. For one thing, most studies are using self-report methods and lacks longitudinal researches [13]. For another, neurologically, during the fMRI scanning, drugs have an apparent impact to our brain areas while the Internet, specifically social media use, does not alter our brain significantly [14].

On the other hand, most scientists and researchers, especially behavioral science experts, still suggest the excessive use of social media as an addictive behavior due to the 'dependency' feature of using social media [15]. What differentiate normally overuse of social media and social media 'addiction' would be the compulsive behavior and unfavorable consequences when individuals are not able to control their impulse to use social media [16]. When individuals exhibit compulsive behavior to social media use, it shares many similarities to the substance abuse, such as 'lack of control when engaging in the behavior' or 'important activities given up' $[17,18]$.

The concept of compulsive social media use may be defined differently. However, most of them were still modified according to the substance abuse disorder defined in DSM. Brown in 1993 developed six criteria (later extended by Griffiths) related to social media addictive use, including salience, mood modification, tolerance, withdrawal symptoms, conflict, and relapse $[17,19]$. More recently, as Facebook became one of the major social platforms used by adolescents, according to the general addiction theory, Andreassen and colleagues [16] developed the Bergen Facebook Addiction Scale (BFAS) consisting of six items, focusing on different dimensions of addictive behavior. Subsequently, Andreassen revised BFAS due to the necessity to measure the usage of other social media platforms. Bergen Social Media Addiction Scale (BSMAS) [20] was then applied to test on social media addiction in general.

Though social media connects people in the virtual world, the overuse of social media can easily traumatize the adolescents' real world connection. Social media addiction predicts adolescents' negative social connectiveness, which can be explained by attachment style [2], real social environments, longlines, peers and friendships, communication and socialization skill, intimate relationship, and personality traits [21]. Since social media addiction has not been officially categorized into the DSM-5, the following discussions will still refer it to the 'excessive use of social media' or 'excessive social media use'.

\subsection{The Application of Mindfulness in Social Media Excessive Use}

Whereas, the excessive use of social media has been considered as a critical problem not only to individuals and families, but also to the society. Fortunately, the interventions have showed to have positive influence to reduce students' excessive social media use and to enhance the academic efficiency [22]. Mindfulness can be a particularly self-generated belief system or a learned value system that promotes self-regulation [23]. To enhance individual's well-being, mindfulness would be helpful to individuals' conducive coping mechanism while suppress the maladaptive coping strategies [24]. The concept of mindfulness could be used as a personal trait (trait or dispositional mindfulness) that individual is able to aware of and concern about the current situation without judgment and attachment [25], or as an awareness (state mindfulness) [26] that individuals practice in interventions and sessions [27]. Without trainings or interventions, trait mindfulness has been shown to stay consistent over time [28]. In this paper, the mindfulness would refer to the trait mindfulness, if without any further explanation. One major measurement for individual's mindfulness is The Mindful Attention Awareness Scale (MAAS), which consisted of questions assessing mindfulness and mindlessness. The assessment concentrated on diverse domains (cognitive, emotional, physical, interpersonal, general) and is analyzed based on a six-point Likert scale ranging from 1 (almost always) to 6 (almost never). When individuals are scored high in the assessment, it reflects a high level of trait mindfulness

However, there still existed uncertainty and concerns regarding the application of mindfulness. Reports have shown that mindfulness-based intervention (MBI) has led to executive memory impairments, depersonalization, panic attacks, psychotic episodes, addiction (i.e., to mindfulness) etc. [29]. This paper will review articles' relating the excessive use of social media and mindfulness, and to discuss 1). if mindfulness could help reducing the social media addictive behavior, and 2 ). how do individuals with higher trait mindfulness different from those with lower trait mindfulness in regards to the problematic social media use, and 3 ). the role does mindfulness play in the intervention for the excessive use of social media addiction.

\section{METHOD}

In order to identify relevant literature, Scopus and Web of Science were used to search the literature. The search was conducted in September, 2021 and keywords were limited to "social media", "social network", 
combined with addiction-relevant words, including "addiction, problematic use", "excessive use", and "compulsive use", and "mindfulness" and "mindfulness techniques". Results were included if the studies were 1) written in English, 2) focused on the topic of social media addiction and applied mindfulness techniques, 3) contain empirical data in the research (exclude review articles) as summarized in Table 1.

Table 1: Summaries for eleven articles

\begin{tabular}{|c|c|c|c|c|c|c|}
\hline Title & $\begin{array}{l}\text { Author } \\
\text {, year }\end{array}$ & Number & $\begin{array}{l}\text { Count } \\
\text { ry }\end{array}$ & $\begin{array}{l}\text { Measurement for } \\
\text { excessive social } \\
\text { media use }\end{array}$ & $\begin{array}{l}\text { Measurement for } \\
\text { mindfulness }\end{array}$ & Summary \\
\hline $\begin{array}{l}\text { Mindfulness, Compulsive } \\
\text { Mobile Social Media Use, } \\
\text { and Derived Stress: } \\
\text { The Mediating Roles of } \\
\text { Self-Esteem and Social } \\
\text { Anxiety }\end{array}$ & $\begin{array}{l}\text { Apaola } \\
\text { za et } \\
\text { al. } \\
\text { (2019) }\end{array}$ & $\begin{array}{l}346 \\
\text { undergra } \\
\text { duate } \\
\text { students } \\
\text { aging } \\
\text { from } 17 \\
\text { to } 26 \\
\text { year } \\
\text { (M=18.74 } \\
\text { years } \\
\text { old) }\end{array}$ & & $\begin{array}{l}\text { Five-item scale } \\
\text { assessing } \\
\text { Whatsapp } \\
\text { application } \\
\text { usage }\end{array}$ & $\begin{array}{l}\text { Adapted Five- } \\
\text { Facet Mindfulness } \\
\text { Questionnaire } \\
{[30] \text { to the }} \\
\text { context of social } \\
\text { media use }\end{array}$ & $\begin{array}{l}\text { Regression coefficients } \\
\text { suggested mindfulness to have a } \\
\text { direct negative effect on } \\
\text { compulsive social network site } \\
\text { usage ( } p<0.001) \text {. The influence } \\
\text { of mindfulness to reduce } \\
\text { compulsive social media use is } \\
\text { mediated by positive effects on } \\
\text { self-esteem and negative effects } \\
\text { on social anxiety. }\end{array}$ \\
\hline $\begin{array}{l}\text { Internet Addiction and } \\
\text { Depression in Chinese } \\
\text { Adolescents: A Moderated } \\
\text { Mediation Model }\end{array}$ & $\begin{array}{l}\text { Chi, et } \\
\text { al. } \\
\text { (2019) }\end{array}$ & $\begin{array}{l}522 \\
\text { middle } \\
\text { schoolers } \\
(\mathrm{M}= \\
12.33 \\
\text { years } \\
\text { old })\end{array}$ & China & $\begin{array}{l}\text { Ten-item } \\
\text { Internet } \\
\text { addiction test } \\
\text { [31] }\end{array}$ & $\begin{array}{l}\text { Ten-item Child } \\
\text { and Adolescent } \\
\text { Mindfulness } \\
\text { Measure (CAMM) } \\
{[32]}\end{array}$ & $\begin{array}{l}\text { The interaction between Internet } \\
\text { addiction and mindfulness is not } \\
\text { significant ( } \beta=-0.02, p>0.05) \text {. } \\
\text { Mindfulness plays the role as } \\
\text { moderator between Internet } \\
\text { Addiction and depression. }\end{array}$ \\
\hline $\begin{array}{l}\text { Demystifying the Dark } \\
\text { Side of Social Networking } \\
\text { Sites through Mindfulness }\end{array}$ & $\begin{array}{l}\text { Hassa } \\
\mathrm{n} \\
(2021))\end{array}$ & $\begin{array}{l}236 \\
\text { online } \\
\text { participa } \\
\text { nts }\end{array}$ & & $\begin{array}{lr}\text { Compulsive } & \text { SNS } \\
\text { usage } & \text { was } \\
\text { measured } & \text { by } \\
\text { Turel and } & \text { Osatuyi's scale } \\
\text { [30] } & \end{array}$ & $\begin{array}{l}\text { Baer et al. 's } \\
(2006) \quad \text { Trait } \\
\text { Mindfulness Scale } \\
{[33]}\end{array}$ & $\begin{array}{l}\text { Mindfulness was negatively and } \\
\text { significantly associated with } \\
\text { compulsive SNS use }(b=-0.426 \text {, } \\
p<0.001)\end{array}$ \\
\hline $\begin{array}{l}\text { Face it, don't Facebook it: } \\
\text { Impacts of Social Media } \\
\text { Addiction on Mindfulness, } \\
\text { Coping Strategies and the } \\
\text { Consequence on } \\
\text { Emotional Exhaustion }\end{array}$ & $\begin{array}{l}\text { Sriwilai } \\
\& \\
\text { Charo } \\
\text { ensuk } \\
\text { mongk } \\
\text { ol } \\
(2015)\end{array}$ & $\begin{array}{l}211 \\
\text { employe } \\
\text { es from } \\
13 \\
\text { different } \\
\text { compani } \\
\text { es } \\
\text { (M=31.56 } \\
\text { years } \\
\text { old) }\end{array}$ & $\begin{array}{l}\text { Thaila } \\
\text { nd }\end{array}$ & $\begin{array}{l}\text { Bergen Facebook } \\
\text { Addiction Scale } \\
\text { developed by } \\
\text { Andreassen et al. } \\
\text { [11] }\end{array}$ & $\begin{array}{l}\text { Mindfulness } \\
\text { Attention and } \\
\text { Awareness Scale } \\
\text { (MAAS) } \\
\text { developed by } \\
\text { Brown and Ryan } \\
{[35]}\end{array}$ & $\begin{array}{l}\text { Result shows a negative } \\
\text { relationship and highly } \\
\text { significance between social } \\
\text { media addiction and } \\
\text { mindfulness. }(\beta=0.356, p<0.001) \text {. }\end{array}$ \\
\hline $\begin{array}{lr}\text { Trait } & \text { emotional } \\
\text { intelligence } & \text { and } \\
\text { problematic } & \text { online } \\
\text { behaviors } & \text { among } \\
\text { adolescents: } & \text { The } \\
\text { mediating } & \text { role of } \\
\text { mindfulness, rumination, } \\
\text { and depression }\end{array}$ & $\begin{array}{l}\text { Kircab } \\
\text { urun } \\
\text { et al. } \\
\text { (2019) }\end{array}$ & $\begin{array}{l}470 \\
\text { adolesce } \\
\text { nts } \\
(\mathrm{M}=16.29 \\
\text { years } \\
\text { old })\end{array}$ & $\begin{array}{l}\text { Turke } \\
\text { y }\end{array}$ & $\begin{array}{l}\text { Bergen Social } \\
\text { Media Addiction } \\
\text { Scale } \\
\text { (BSMAS)[20] }\end{array}$ & $\begin{array}{l}\text { Mindful Attention } \\
\text { Awareness Scale } \\
\text { (MAAS) [35] }\end{array}$ & $\begin{array}{l}\text { mindfulness was a significant } \\
\text { mediator between trait } \\
\text { Emotional Intelligence and } \\
\text { Problematic social media use }\end{array}$ \\
\hline
\end{tabular}




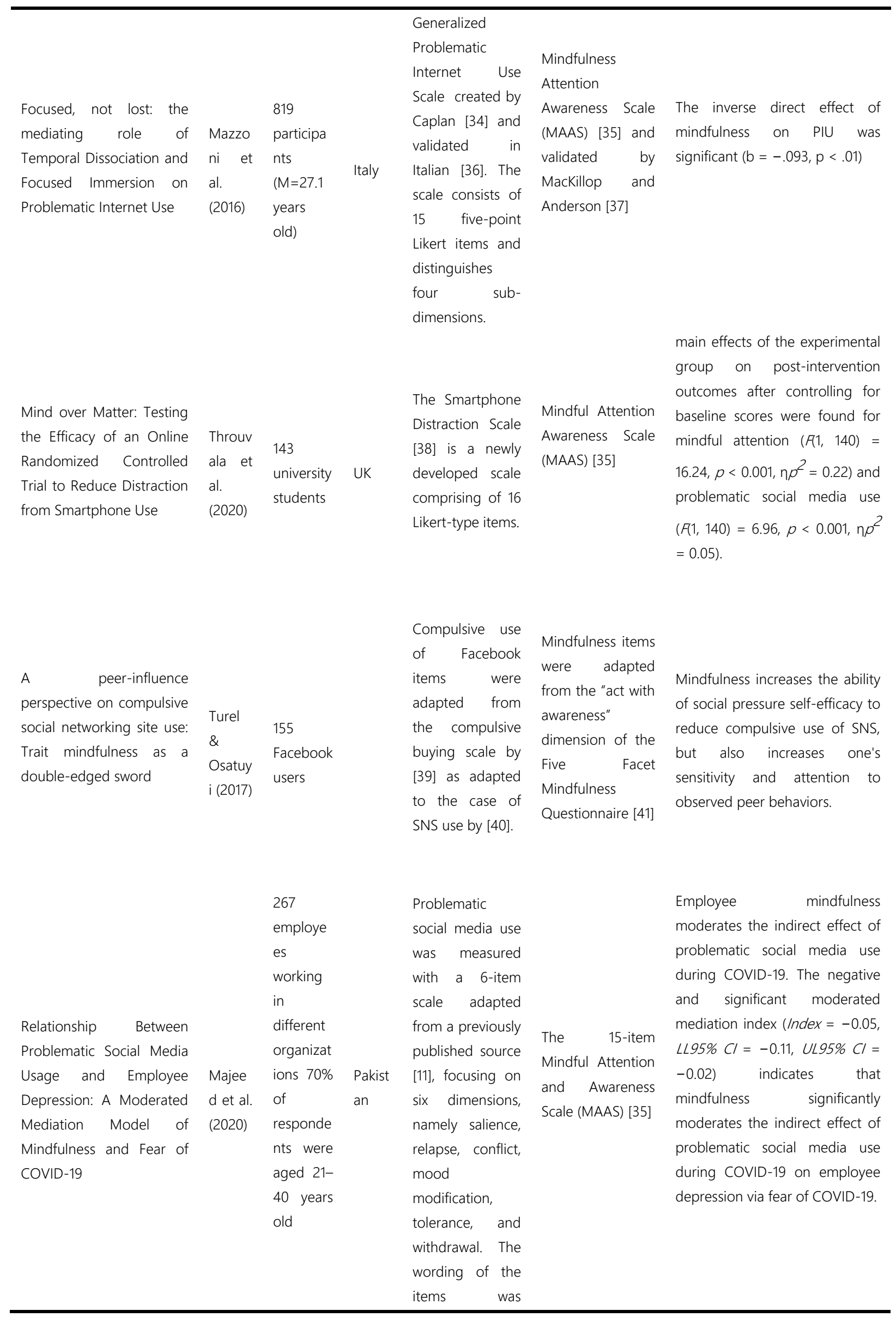




\begin{tabular}{|c|c|c|c|c|c|c|}
\hline & & & & $\begin{array}{l}\text { modified to } \\
\text { capture social } \\
\text { media use during } \\
\text { COVID-19. }\end{array}$ & & \\
\hline & & 298 & & $\begin{array}{l}\text { Used Chen } \\
\text { Internet } \\
\text { Addiction Scale } \\
\text { (CIAS) [42] to }\end{array}$ & & \\
\hline $\begin{array}{l}\text { Trait Mindfulness as a } \\
\text { Protective Factor in } \\
\text { Connections between } \\
\text { Psychological Issues and } \\
\text { Facebook Addiction } \\
\text { among } \\
\text { Turkish University Students }\end{array}$ & $\begin{array}{l}\text { Eskisu } \\
\text { et al. } \\
(2020)\end{array}$ & $\begin{array}{l}\begin{array}{l}\text { college } \\
\text { students } \\
(M\end{array}= \\
21.61 \\
\text { years } \\
\text { old })\end{array}$ & $\begin{array}{l}\text { Turke } \\
\text { y }\end{array}$ & $\begin{array}{l}\text { measure } \\
\text { participants' } \\
\text { addictive } \\
\text { Facebook use, } \\
\text { modifying the } \\
\text { scale to refer to } \\
\text { "Face- book" } \\
\text { when the scale } \\
\text { otherwise } \\
\text { referenced "the } \\
\text { internet". }\end{array}$ & $\begin{array}{l}\text { Mindful Attention } \\
\text { Awareness Scale } \\
\text { (MAAS) [35] }\end{array}$ & $\begin{array}{l}\text { Mindfulness was significantly } \\
\text { and inversely associated with } \\
\text { Facebook addiction }(\beta=-.38, S E \\
=.06, p<.001) \text {. }\end{array}$ \\
\hline $\begin{array}{l}\text { An Examination of College } \\
\text { Students' Social Media } \\
\text { Use, Fear of Missing Out, } \\
\text { and Mindful Attention }\end{array}$ & $\begin{array}{l}\text { Weave } \\
r \quad \& \\
\text { Swank } \\
(2020)\end{array}$ & $\begin{array}{l}278 \\
\text { undergra } \\
\text { duate } \\
\text { students } \\
(M \quad= \\
20.5 \\
\text { years } \\
\text { old })\end{array}$ & $\begin{array}{l}\text { Unite } \\
\mathrm{d} \\
\text { States }\end{array}$ & $\begin{array}{l}\text { Social Media Use } \\
\text { Questionnaire } \\
\text { [43] was } \\
\text { developed based } \\
\text { on gambling } \\
\text { addiction } \\
\text { symptoms } \\
\text { described in the } \\
\text { Diagnostic and } \\
\text { Statistical Manual } \\
\text { of Mental } \\
\text { Disorders [5]. } \\
\text { The ques- } \\
\text { tionnaire consists } \\
\text { of nine items }\end{array}$ & $\begin{array}{l} \\
\text { Mindful Attention } \\
\text { Awareness Scale } \\
\text { [35] }\end{array}$ & $\begin{array}{l}\text { There was a statistically } \\
\text { significant, small inverse } \\
\text { correlation between PSMU and } \\
\text { mindful attention ( } r=-.30, p \\
<.01) \text {. }\end{array}$ \\
\hline
\end{tabular}

\section{RESULT}

The original search was 56 articles, 45 were excluded of irrelevance or repetition. Finally, a total of 11 articles fulfilled the inclusion criteria and were analyzed in this review paper. All studies were conducted within the last seven years (2015-2021). Overall, 3755 participants were analyzed in eleven articles. Among different age groups, four articles [4447] studied 1065 undergraduate students, two articles [48, 49] focused on 992 adolescents, two papers [9, 50] researched on 478 adult company employees, and three other articles [30] [51, 52] consisting of 1210 participants draw the data online, with no specification on participants' age.

\section{DISCUSSIONS}

Multiple researches found that excessive use of social media has caused negative consequences such as psychological vulnerability, sleep deprivation, and lower study and working efficiency, etc. [2, 3, 11]. Thus, ideologically, by managing appropriate online social media use, it would in some extent mediating the situation. However, as the school systems are relying more on the Internet and social media platforms (needless to mention the online class worldwide due to the pandemic), it is not feasible to ask for students limiting their use on social media and Internet using. Mindfulness, in recent years, has been used as interventions to ameliorate cravings, substance use disorders, and post-traumatic stress disorder [45]. It is 
suggested that by controlling the self-awareness of behaviors may decrease the tendency of disruptive behaviors and promote positive achievements [53]. Thus, multiples researches are focusing on the behavioral aspects of how mindfulness could enhance the healthy use of social media and prevent problematic social media use. Nevertheless, not many studies have put focus on reviewing these two factors. This review paper mainly studies the relationship between excessive social media use and mindfulness.

Concerning the demographic distribution of the sample populations, most age groups (adolescents, undergraduate students, employees, anonymous online users) are facing with the problem of excessive use of social media. Besides, most age groups are benefited from a high level of trait mindfulness, which can lead to greater mental well-being, alleviating stressful and depressive thoughts, and improving quality of life [9]. On the other hand, the paper were extracted from China [48], Thailand [9], Turkey [46, 49], Italy [52], United Kingdom (Throuvala et al., 2020), Pakistan [50], and the United States [47]. With a broad covering from East to the West, it seems that more countries and researchers are focusing on the interrelationship between excessive social media use and mindfulness.

Concerning the measurement for the level of excessive social media use, all articles used different version of questionnaires and asked participants to answer questions on a Likert scale, such as Internet Addiction Test [48], Bergen Facebook Addiction Scale [9], Bergen Social Media Addiction Scale [49], Chen Internet Addiction Scale [46], the Social Media Questionnaire [47], etc. For the mindfulness measurement, most applied Mindful Attention Awareness Scale (MAAS) [35] developed by Brown and Ryan [9, 45-47, 49, 50, 52], while few applied other measurement, e.g., Five-Facet Mindfulness Questionnaire [30, 44], Child and Adolescent Mindfulness Measure (CAMM) [48], and Baer et al.'s Trait Mindfulness Scale [51]. Similar to that of the social media use measurement, all studies were tested on a Likert-scale questionnaire.

In selected articles, all tested on individual's mindfulness as a trait or personality instead of a training tool or intervention technique. Most have showed a significant inverse relationship between mindfulness and compulsive social media use $[9,30,44][45-47,49$, 51, 52], while Chi and colleagues [48] and Majeed and colleagues' [50] study shows that the interaction between social media addiction and mindfulness is insignificant. On the other hand, some studies put mindfulness as a mediating role [49, 52] for other behavioral consequences while some also use mindfulness as a moderator $[48,50]$ to investigate excessive use of social media.

Concerning the connection between mindfulness and excessive social media use, multiple researches have included emotional-related issues. In Apaolaza and colleagues' research [44], self-esteem and social anxiety were studied; depression were discussed in three articles [9, 48-50]; general psychological issues were focused in Eskisu and colleagues' article [46]; and emotional exhaustion were talked about in Sriwilai and Charoensukmongkol's paper [9]. For the underlying mechanism of how mindfulness reduces excessive social media use, multiple papers mentioned the roles of selfesteem and social anxiety as mediators for the positive effect of mindfulness on excessive use of social media $[44,48]$.

Although these articles have studied over three thousand participants, there still exist several limitations and future implications. One major concern is that all eleven articles were using cross-sectional research design. Future studies might use the longitudinal design for this area. Also, all papers were using questionnaires to test on the level of social media use and mindfulness, other method should be applied, such as experiments or interviews.

\section{CONCLUSION}

Overall, the findings showed that adolescents with higher level of mindfulness tend to have a higher potential to involve into negative social media addictive behaviors. Therefore, suggestions should be called for. Most significantly, not only parents and teachers should guide for adolescents, as the problematic social media use behavior happens across different ages, everyone should be aware of the negative consequences brought by the excessive use of social media. Thus, mindfulness training sessions or seminars should be adopted more frequently to school, community, and working environments in future.

\section{REFERENCES}

[1] Kennedy, T. L. M., Smith, A., Wells, A. T., \& Wellman, B. (2008). Networked families. Pew internet \& American life project. Retrieved February, 17, 2009.

[2] D’Arienzo, M. C., Boursier, V., \& Griffiths, M. D. (2019). Addiction to social media and attachment styles: a systematic literature review. International Journal of Mental Health and Addiction, 17(4), 1094-1118.

[3] Busch, P. A., \& McCarthy, S. (2021). Antecedents and consequences of problematic smartphone use: A systematic literature review of an emerging research area. Computers in human behavior, 114, 106414.

[4] Soper, W. B., \& Miller, M. J. (1983). Junk-time junkies: An emerging addiction among 
students. The School Counselor, 31(1), 40-43.

[5] American Psychiatric Association, D. S., \& American Psychiatric Association. (2013). Diagnostic and statistical manual of mental disorders: DSM-5.

[6] Pinna, F. E. D. E. R. I. C. A., Dell'Osso, B., Di Nicola, M., Janiri, L., Altamura, A. C., Carpiniello, B. E. R. N. A. R. D. O., \& Hollander, E. (2015). Behavioural addictions and the transition from DSM-IV-TR to DSM-5. Journal of Psychopathology, 21(4), 380-389.

[7] Brewer, J. A., Sinha, R., Chen, J. A., Michalsen, R. N., Babuscio, T. A., Nich, C., ... \& Rounsaville, B. J. (2009). Mindfulness training and stress reactivity in substance abuse: results from a randomized, controlled stage I pilot study. Substance Abuse, 30(4), 306-317.

[8] Appel, J., \& Kim-Appel, D. (2009). Mindfulness: Implications for substance abuse and addiction. International Journal of Mental Health and Addiction, 7(4), 506.

[9] Sriwilai, K., \& Charoensukmongkol, P. (2016). Face it, don't Facebook it: impacts of social media addiction on mindfulness, coping strategies and the consequence on emotional exhaustion. Stress and Health, 32(4), 427-434.

[10] Brewer, J. (2019). Mindfulness training for addictions: has neuroscience revealed a brain hack by which awareness subverts the addictive process?. Current opinion in psychology, 28, 198203.

[11] Griffiths, M. D. (2012). Facebook addiction: Concerns, criticism, and recommendations: A response to Andreassen and colleagues. Psychological Reports, 110, 518-520. https://doi.org/10.2466/01.07.18.PR0.110.2.518520

[12] Junco, R. (2012). The relationship between frequency of Facebook use, participation in Facebook activities, and student engagement. Computers \& Education, 58, 162-171. https://doi.org/10.1016/j.compedu.2011.08.004

[13] Zendle, David, and Henrietta Bowden-Jones. "Is Excessive Use of Social Media an Addiction?" BMJ (Online) 365 (2019): 12171-12171. Web.

[14] Burhan, R., \& Moradzadeh, J. (2020). Neurotransmitter dopamine (DA) and its role in the development of social media addiction. Journal of Neurology \& Neurophysiology, 11(7), 1-2.

[15] Alavi, S. S., Ferdosi, M., Jannatifard, F., Eslami, M., Alaghemandan, H., \& Setare, M. (2012).
Behavioral addiction versus substance addiction: Correspondence of psychiatric and psychological views. International journal of preventive medicine, 3(4), 290.

[16] Andreassen, C. S. (2015). Online social network site addiction: A comprehensive review. Current Addiction Reports, 2, 175-184. https://doi.org/10.1007/s40429-015-0056-9

[17] Griffiths, M. (1996). Behavioural addiction: an issue for everybody?. Employee Councelling Today.

[18] Griffiths, M. D. (2000). Internet addiction: Time to be taken seriously? Addiction Research, 8, 413418. https://doi.org/10.3109/16066350009005587

[19] Brown, R. I. F. (1993). Some contributions of the study of gambling to the study of other addictions. In W. R. Eadington \& J. Cornelius (Eds.), Gambling behavior and problem gambling (pp. 241-272). Reno, NV: University of Nevada Press.

[20] Andreassen, C. S., Pallesen, S., \& Griffiths, M. D. (2017). The relationship between addictive use of social media, narcissism, and self-esteem: Findings from a large national survey. Addictive behaviors, 64, 287-293.

[21] Savci, M., \& Aysan, F. (2017). Technological addictions and social connectedness: predictor effect of internet addiction, social media addiction, digital game addiction and smartphone addiction on social connectedness. Dusunen Adam: Journal of Psychiatry \& Neurological Sciences, 30(3), 202216.

[22] Franco, C., Mañas, I., Cangas, A. J., \& Gallego, J. (2010, September). The applications of mindfulness with students of secondary school: Results on the academic performance, self-concept and anxiety. In World Summit on Knowledge Society (pp. 83-97). Springer, Berlin, Heidelberg.

[23] Evans, D. R., Baer, R. A., \& Segerstrom, S. C. (2009). The effects of mindfulness and selfconsciousness on persistence. Personality and Individual Differences, 47(4), 379-382.

[24] Baer, R. A. (2009). Self-focused attention and mechanisms of change in mindfulness-based treatment. Cognitive behaviour therapy, $38(\mathrm{~S} 1)$, 15-20.

[25] Brown KW, Creswell JD, Ryan RM, eds. (2015) Handbook of mindfulness: theory, research, and practice. New York, NY: Guilford Publications.

[26] Randal C, Pratt D, Bucci S. Mindfulness and selfesteem: a systematic review. Mindfulness 2015; 6:1366-1378. 
[27] Lau, M. A., Bishop, S. R., Segal, Z. V., Buis, T., Anderson, N. D., Carlson, L., ... \& Devins, G. (2006). The Toronto mindfulness scale: Development and validation. Journal of clinical psychology, 62(12), 1445-1467.

[28] Kiken, L. G., Garland, E. L., Bluth, K., Palsson, O. S., \& Gaylord, S. A. (2015). From a state to a trait: Trajectories of state mindfulness in meditation during intervention predict changes in trait mindfulness. Personality and Individual Differences, 81, 41-46. https://doi.org/10.1016/j.paid.2014.12.044

[29] Van Gordon, W., Shonin, E., \& Garcia-Campayo, J. (2017). Are there adverse effects associated with mindfulness?.

[30] Turel O, Osatuyi B. A peer-influence perspective on com- pulsive social networking site use: trait mindfulness as a double-edged sword. Computers in Human Behavior 2017; 77:47-53.

[31] Young, K. S., \& De Abreu, C. N. (Eds.). (2010). Internet addiction: A handbook and guide to evaluation and treatment. John Wiley \& Sons.

[32] Greco, L. A., Baer, R. A., \& Smith, G. T. (2011). Assessing mindfulness in children and adolescents: development and validation of the Child and Adolescent Mindfulness Measure (CAMM). Psychological assessment, 23(3), 606.

[33] Baer R. A., Smith G. T., Hopkins J., Krietemeyer J., Toney L. (2006). Using self-report assessment methods to explore facets of mindfulness. Assessment 13 27-45 $10.1177 / 1073191105283504$

[34] Caplan, S. E. (2010). Theory and measurement of generalized problematic Internet use: A two-step approach. Computers in human behavior, 26(5), 1089-1097.

[35] Brown, K. W., \& Ryan, R. M. (2003). The benefits of being present: mindfulness and its role in psychological well-being. Journal of personality and social psychology, 84(4), 822.

[36] Fioravanti, G., Primi, C., \& Casale, S. (2013). Psychometric Evaluation of the Generalized Problematic Internet Use Scale 2 in an Italian Sample. Cyberpsychology, Behavior and Social Networking, 16(10), 761-766. https://doi.org/10.1089/cyber.2012.0429

[37] MacKillop, J., \& Anderson, E. J. (2007). Further psychometric validation of the mindful attention awareness scale (MAAS). Journal of Psychopathology and Behavioral Assessment, 29(4), 289-293.
[38]Throuvala,M.A.;Pontes,H.;Griffiths,M.D.;Rennolds on,M.;Kuss,D.J.Developmentandvalidationof the Smartphone Distraction Scale (SDS): A cognitive and emotion regulation construct. Manuscr. Submitt. Publ. 2020.

[39] Faber, R. J., \& O'guinn, T. C. (1992). A clinical screener for compulsive buying. Journal of consumer Research, 19(3), 459-469.

[40] Serenko, A., \& Turel, O. (2015). Integrating technology addiction and use: An empirical investigation of Facebook users. AIS Transactions on Replication Research, 1(1), 2.

[41] Baer, R. A., Smith, G. T., Hopkins, J., Krietemeyer, J., \& Toney, L. (2006). Using self-report assessment methods to explore facets of mindfulness. Assessment, 13(1), 27-45.

[42] Chen, S. H., Weng, L. J., Su, Y. J., Wu, H. M., \& Yang, P. F. (2003). Development of a Chinese Internet addiction scale and its psychometric study. Chinese Journal of Psychology.

[43] Xanidis, N., \& Brignell, C. M. (2016). The association between the use of social network sites, sleep quality and cognitive function during the day. Computers in human behavior, 55, 121-126.

[44] Apaolaza, V., Hartmann, P., D'Souza, C., \& Gilsanz, A. (2019). Mindfulness, compulsive mobile social media use, and derived stress: The mediating roles of self-esteem and social anxiety. Cyberpsychology, Behavior, and Social Networking, 22(6), 388-396.

[45] Throuvala, M. A., Griffiths, M. D., Rennoldson, M., \& Kuss, D. J. (2020). Mind over matter: testing the efficacy of an online randomized controlled trial to reduce distraction from smartphone use. International journal of environmental research and public health, 17(13), 4842.

[46] Eşkisu, M., Çam, Z., Gelibolu, S., \& Rasmussen, K. R. (2020). Trait Mindfulness as a Protective Factor in Connections between Psychological Issues and Facebook Addiction among Turkish University Students. Studia Psychologica, 62(3), 213-231.

[47] Weaver, J. L., \& Swank, J. M. (2021). An Examination of College Students' Social Media Use, Fear of Missing Out, and Mindful Attention. Journal of College Counseling, 24(2), 132-145.

[48] Chi, X., Liu, X., Guo, T., Wu, M., \& Chen, X. (2019). Internet addiction and depression in chinese adolescents: a moderated mediation model. Frontiers in psychiatry, 10, 816. 
[49] Kircaburun, K., Griffiths, M. D., \& Billieux, J. (2019). Trait emotional intelligence and problematic online behaviors among adolescents: The mediating role of mindfulness, rumination, and depression. Personality and individual differences, 139, 208-213.

[50] Majeed, M., Irshad, M., Fatima, T., Khan, J., \& Hassan, M. M. (2020). Relationship between problematic social media usage and employee depression: a moderated mediation model of mindfulness and fear of CoViD-19. Frontiers in psychology, 11, 3368.

[51] Hassan, Y., \& Pandey, J. (2021). Demystifying the
Dark Side of Social Networking Sites through Mindfulness. Australasian Journal of Information Systems, 25.

[52] Mazzoni, E., Cannata, D., \& Baiocco, L. (2017). Focused, not lost: the mediating role of Temporal Dissociation and Focused Immersion on Problematic Internet Use. Behaviour \& Information Technology, 36(1), 11-20.

[53] Wilmer, H.H.; Sherman, L.E.; Chein, J.M. Smartphones and cognition: A review of research exploring the links between mobile technology habits and cognitive functioning. Front. Psychol. 2017,8 . 